\title{
Indoleamine 2,3-dioxygenase-1 (IDO1) expression by childhood acute myeloid leukemias inhibits T-cell production of IFN- $\gamma$ and confers an unfavorable prognosis
}

\author{
Sergio Rutella ${ }^{1 *}$, Valentina Folgiero ${ }^{1}$, Perla Filippini ${ }^{1}$, Valentina Bertaina ${ }^{1}$, Riccardo Masetti ${ }^{2}$, Marco Zecca ${ }^{3}$, \\ Giuseppina Li Pira', Giovanni F Torelli ${ }^{4}$, Anna Maria Testi ${ }^{4}$, Alice Bertaina ${ }^{1}$, Andrea Pession ${ }^{2}$, Franco Locatelli, ${ }^{1,5}$ \\ From Society for Immunotherapy of Cancer 28th Annual Meeting \\ National Harbor, MD, USA. 8-10 November 2013
}

Indoleamine 2,3-dioxygenase 1 (IDO1) degrades tryptophan into kynurenine (KYN) and other immune suppressive molecules that inhibit effector $\mathrm{T}$ cells and promote regulatory $\mathrm{T}$-cell differentiation. We have previously shown that IDO1 mRNA and protein are detectable in blast cells from $52 \%$ of adults with newly diagnosed acute myeloid leukemia (AML). Herein, we investigated IDO1 expression and function in 41 children with AML (median age $=10$ years, range 1-17). In 20/41 cases, leukemia blast cells up-regulated IDO1 after in vitro challenge with IFN- $\gamma$. Of interest, microenvironmental IFN- $\gamma$ was higher in IDO(pos) compared with IDO(neg) patients. In line with these results, bone marrow (BM)-resident $\mathrm{T}$ cells produced more IFN- $\gamma$, but not IL- 4 or IL-17, compared with $\mathrm{T}$ cells from normal BM samples. KYN levels significantly increased in supernatants of IFN- $\gamma$-stimulated AML cells $(21.0 \mu \mathrm{M} / \mathrm{L}$, range 6.1-36.0) compared with unstimulated cultures $(0.85 \mu \mathrm{M} / \mathrm{L}$, range $0.4-1.7 ; \mathrm{p}=0.0022)$, in parallel with tryptophan consumption $(2.95 \mu \mathrm{M} / \mathrm{L}$, range 1.0-37.0, after challenge with IFN- $\gamma$ compared with 38.1 $\mu \mathrm{M}$, range 18.2-50.0, in unstimulated cultures; $\mathrm{p}<0.0001$ ). In a mixed tumor cell lymphocyte culture, AML blasts primed with IFN- $\gamma$ inhibited Th1 cytokine production by allogeneic CD8+ and, to a lesser extent, CD4+ T cells, while enhancing Th2 cytokine release. The provision of $\mathrm{D}$, L-1-methyl-tryptophan (1MT), an IDO inhibitor, to $\mathrm{T}$-cell/AML co-cultures partially restored IFN- $\gamma$ production by both CD4+ and CD $8+\mathrm{T}$ cells. Furthermore,

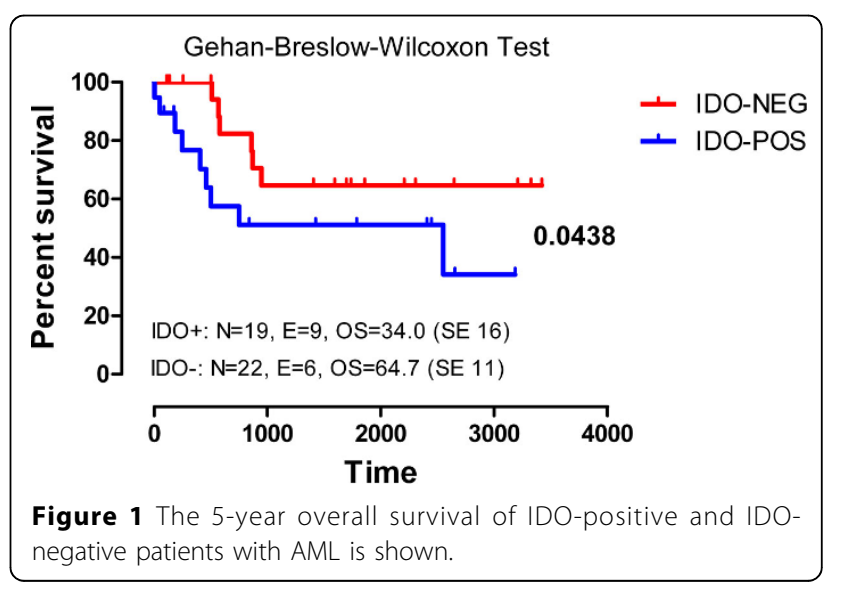

IDO-expressing AML blasts inhibited NK-cell degranulation, as measured through CD107a expression. Finally, 5year overall survival was significantly better for IDO(neg) patients (34 months) compared with IDO(pos) ones (64.7 months; $\mathrm{p}=0.0438$; Figure 1). In conclusion, IDO suppresses Th1 responses/NK activity and may portend an unfavorable prognosis in childhood AML.

\footnotetext{
Authors' details

${ }^{1}$ Pediatric Hematology/Oncology, IRCCS Bambino Gesù Children's Hospital, Rome, Italy. ${ }^{2}$ Pediatric Hematology/Oncology "Lalla Seràgnoli", Univeristy of Bologna, Bologna, Italy. ${ }^{3}$ Pediatric Hematology/Oncology, IRCCS Fondazione San Matteo, Pavia, Italy. ${ }^{4}$ Hematology, University La Sapienza, Rome, Italy. ${ }^{5}$ Pediatrics, University of Pavia, Pavia, Italy.
} 
doi:10.1186/2051-1426-1-S1-P172

Cite this article as: Rutella et al:: Indoleamine 2,3-dioxygenase-1 (IDO1) expression by childhood acute myeloid leukemias inhibits T-cell

production of IFN- $\gamma$ and confers an unfavorable prognosis. Journal for ImmunoTherapy of Cancer 2013 1(Suppl 1):P172.

Submit your next manuscript to BioMed Central and take full advantage of:

- Convenient online submission

- Thorough peer review

- No space constraints or color figure charges

- Immediate publication on acceptance

- Inclusion in PubMed, CAS, Scopus and Google Scholar

- Research which is freely available for redistribution

Submit your manuscript at www.biomedcentral.com/submit
() Biomed Central 